\title{
FACTORS AFFECTING THE LEARNING SPIRIT OF STUDENTS
}

\author{
Dewi Nuning Nurna*, Wibowo Rudi, Lecturers of Economics \\ University of Maarif Hasyim Latif, Indonesia \\ *E-mail: nuning@dosen.umaha.ac.id
}

\begin{abstract}
The purpose of this study is to determine and analyze the magnitude of the influence of the factors of Lecturer Competence, Student Psychology, and Learning Environment on the Student's Spirit of Learning at the Faculty of Economics at Maarif Hasyim Latif University Sidoarjo. This research is a qualitative study. In this study the population amounted to 586 students consisting of active students in semester II, IV, VI of the Faculty of Economics at Maarif Hasyim Latif University. The research sample amounted to 59 students using the proportionate stratified random sampling technique of $10 \%$ based on the semester level of the respondents. Data analysis in this study used PLS (Partial Least Square) analysis techniques. The conclusions of this study are: (1) Competence of lecturers has an influence on student learning spirit equal to $17.6 \%$. ; (2) Student Psychology has an influence on student learning spirit equal to $29.7 \%$; (3) the influence of student environment on student learning spirit equal to $18.4 \%$; (4) There is an influence of lecturer competence, student psychology, and learning environment simultaneously on the spirit of learning; (5) Among the lecturer competence, student psychology, learning environment towards student learning spirit which has a dominant value to student learning spirit is student psychology.
\end{abstract}

\section{KEY WORDS}

Human resources, competence, student psychology, learning environment, learning spirit.

The progress of a nation is also sourced from its Human Resources (HR) which has high advantages, namely educators who are able to face all obstacles nowadays until the future. Education is very influential in the development of a nation. Education is a nation's efforts to improve the quality of its human resources (Agbo, 2002; Sulisworo, 2020; Cleary et al., 2009; Banks \& Dohy, 2019; Hota \& Sarangi, 2019; Patel, G., \& Annapoorna, 2019; Fajariah \& Suryo, 2020).

When seen in reality education in Indonesia has not run according to plan so that the government needs to improve the existing system in order the education can run as intended. In Indonesia there are various universities that provide a wide range of fields of science to hone one's abilities deeper. Universities also help the community to find someone's interests and talents. But the lack of public awareness about the importance of education is also an obstacle for the government in succeeding the education goals of the Indonesian nation. Educational success can occur if there is an interaction of cooperation among the government, the community, education staff, educators, and students (Simonson et al., 2019; Thousand et al., 2019; Medina et al., 2019). With that education will succeeding the development in Indonesia and facilitate the community in all scientific fields.

Factors that can affect the learning spirit of the learners namely students, among other factors derived from internal and external. Internal factors are factors that are found in a person so that internal factors are very important in the progress of a person. Internal factors depend on a person's ability to start, maintain, and finish something that was built from the start. The process will determine the success of someone in realizing their dreams. Psychological factors are factors that originate from the person him/herself. Psychological factors are innate factors of a person from birth, for example: interests, talents, intelligence, etc. that are very influential for learners in achieving their achievements (Theron, 2004; Chaika, 2020).

External factors are factors that come from outside of someone which can have positive or negative impacts on internal factors that have been owned by someone, because 
external factors depend on the social environment. Social environment that is not supportive can make internal factors also decrease. And this also has an impact on student achievement which can worsen. All of that depends on a person in dealing with the influence that she/he receives. If we can react and always think positively, we will also be able to distinguish positive and negative impacts from internal and external influences.

Lecturer competencies are needed in student learning activities because students' extrinsic learning motivation also comes from the ability of lecturers. Lecturers are professional educators who must be able to respond to various characteristics of students in the lecture process. Lecturers who have not maximum competencies will have a negative influence on students in lecturing activities. In addition to the factor of student psychological and lecturer competence, environmental factors which included in these external factors also play an important role in student learning achievement. There are various social environmental factors that influence students during college activities. Social environment factors on campus such as college friends, learning facilities, natural environment (air, light, atmosphere) and so forth, while social environmental factors in the community such as the work environment i.e. superiors, coworkers, and work regulations, and so forth. And social environmental factors in the family for example the method of parents educating, family tension, the location of the house, plays an important role in student lecturing activities.

In relation to the world of student education, enthusiasm for learning/learning spirit is indispensable in lectures. The meaning of enthusiasm/spirit in society is often equated with motivation. People who have high motivation will always improve their abilities with positive energy, with that students will continue to enthusiasm in achieving their dreams even though there are many obstacles in achieving them. So that someone who has been motivated to move forward will think more strategically in developing their ideas while following the times.

With the establishment of various universities in Indonesia open new opportunities for people who want to train and hone their thinking power to think ahead and be positive in all fields. But it cannot be denied that a person is not far from his/her parents' upbringing, in the sense of positive or negative influence that exists in a person comes from internal and external factors.

Maarif Hasyim Latif University / Universitas Maarif Hasyim Latif, which is called UMAHA, is a university that has the skills needed by industry now through four faculties through strong research activities in the East Java region. UMAHA is a private university with Islamic religious under the Nahdlatul Ulama organized by the Foundation for Education and Social Maarif / Yayasan Pendidikan and Sosial Maarif (YMP). UMAHA is located on Jalan Raya Ngelom Megare No. 30, Ngelom, Taman, Sidoarjo, East Java. At Maarif Hasyim Latif University, student activity and enthusiasm for learning/learning spirit are still low, this is influenced by various factors. For example: lecturer competencies, inadequate facilities, level of student intelligence, and so on.

Seeing from the description of the problem above, the problem formulation can be formulated among others:

- Does the competency of lecturers have a positive and significant influence on the learning enthusiasm/spirit of students of the Faculty of Economics at Maarif Hasyim Latif University - Sidoarjo?

- Does the psychology of students have a positive and significant influence on the learning enthusiasm/spirit of students of the Faculty of Economics at Maarif Hasyim Latif University - Sidoarjo?

- Does the learning environment have a positive and significant influence on the learning enthusiasm/spirit of students of the Faculty of Economics at Maarif Hasyim Latif University - Sidoarjo?

- Does the competency of lecturers, student psychology, and learning environment simultaneously have a positive and significant influence on the learning enthusiasm of students of the Faculty of Economics at Maarif Hasyim Latif University - Sidoarjo? 
Among the lecturers' competencies, student psychology, learning environment which one has the dominant value on the learning enthusiasm/spirit of students of the Faculty of Economics at Maarif Hasyim Latif University - Sidoarjo?

\section{METHODS OF RESEARCH}

In this research, the object is the Maarif Hasyim Latif University, an Islamic religious private university established by Nahdlatul Ulama, organized by the Maarif Education and Social Foundation / Yayasan Pendidikan and Sosial Maarif (YMP) located on Jalan Ngelom Megare No. 30, Ngelom, Taman, Sidoarjo, East Java. The scope of this study is the response of respondents or students on the Competency of Lecturers, Student Psychology, Learning Environment at the University of Maarif Hasyim Latif - Sidoarjo. The research period was conducted in March - August 2019.

In this study using the quantitative approach method used by researchers, this can be seen through the title of the study and using descriptive statistical data analysis, Next will be discussed also the influence that contained in the independent variable and the dependent variable. This study uses primary data sources.

The data collection of this study, using the distribution of questionnaires with closed answers, so researchers must collect data first after that it was tested to find out the validity and reliability. Data collected using a survey through the distribution of questionnaires submitted to students at Maarif Hasyim Latif University.

This study has 2 types of variables, namely the dependent variable and the independent variable. The independent variables in this study are:

- Lecturer Competency (X1) is an ability that must be lived, possessed, and mastered by a lecturer regarding knowledge, skills, and behavior to be able to carry out his/her professional duties.

- Student Psychology (X2) is an internal or innate factor since born that is studying students' behavior, either as a person and in dealing with their surroundings that can affect the process of student learning activities and can determine the level of student learning achievement

- Learning Environment (X3) is an external factor that can influence development and influence students in their learning process in the physical and social environment.

This study uses the dependent variable as follows. Learning enthusiasm/spirit of the student $(Y)$ is something that arises in students in carrying out learning, gain knowledge, skills, information, through effort, teaching or experience gained.

The researcher uses the Likert scale to measure the assessment of the degree of agreement / disagreement of each respondent (student).

The population in this study were active students of the Faculty of Economics at Maarif Hasyim Latif University semester II, IV, VI totaling: 586 students and this population included in the heterogeneous population because all individual populations have relative individual characteristics, this character which distinguishes individual members from one to others in the population.

In this study using proportionate stratified random sampling technique. Stratified, based on the semester level of the respondent, namely II, IV, VI which is an active semester, meaning that many academic activities of students are carried out in the semester. Whereas for VIII semester students outside of research because they have not participated in many academic activities (free from lectures). Meanwhile proportional is to determine the number of respondents in each study program, semester, and class.

The population of this study was more than 100 people, so that researchers used $10 \%$ of the total population contained in the Faculty of Economics of UMAHA, namely: $586 \times 10 \%$ $=58.6=59$ students (respondents).

The data source used in this study are:

- Primary data, is the source of data obtained directly from respondents. Primary data obtained by questionnaire and interview. The primary data includes several things, among others: 
- Data obtained directly at the university concerned, obtained from students of the Faculty of Economics in the form of questionnaire answers.

- Data that is directly recorded by researchers regarding student data in university documents.

- Secondary data is presented in the form of data, diagrams, tables, or about research topics. This data is an archive that is directly related to this research including short history of the university, the vision and mission of the university, and the organizational structure of faculty at the university.

In this study, researchers chose Structural Equation Modeling (SEM) as a data processing analysis tool, and for statistical techniques using PLS (Partial Least Square). In performing a research analysis conducted the steps as follows:

Table 1 - Test of Validity and Construct Reliability

b. Construct Reliability Test

Table 2 - Measurement of Outer Model and Inner Model Prediction

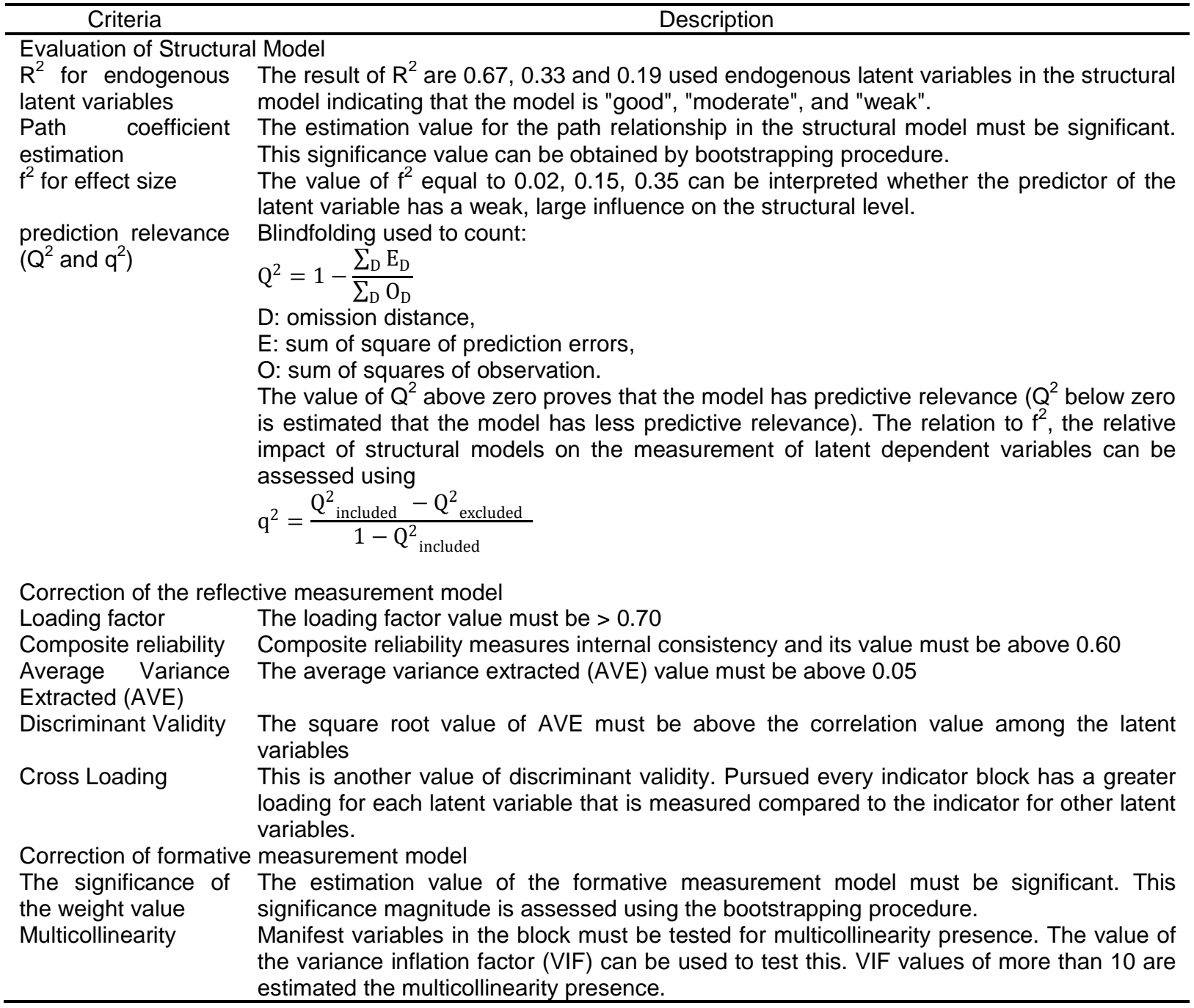


The questionnaire was declared reliable if the respondent's answers could be consistent with the questions asked. In this study the researchers tested the reliability of the questionnaire using the coefficient formula.

SEM begins by developing hypotheses, model representations, and operationalization of variables using measurement instruments and model testing. Common steps in using SEM namely:

1. Perform model specifications;

2. Estimation of independent parameters;

3. Assessment of fit;

4. Model modification;

5. Interpretation and communication of statistical test results and recognition that constructs that built based on the most appropriate model using carefully designed research designs in order to distinguish rival hypotheses;

6. Validation and replication of the model before the study is interpreted and communicated.

In this research used SEM based on variance or component, so that the statistical technique used is PLS (Partial Least Square). PLS parameter estimation divided into 3, namely:

1. Weight estimate;

2. Path estimate;

3. Means and location parameter.

The path analysis model of all latent variables consists of:

1. Inner model;

2. Outer model;

3. Weight relation.

RESULTS OF STUDY

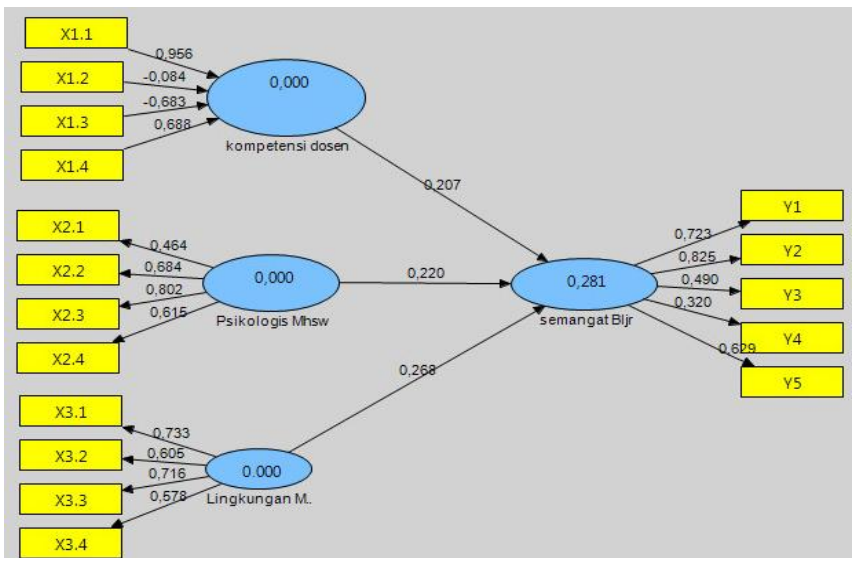

Figure 1 - First Stage PLS Analysis

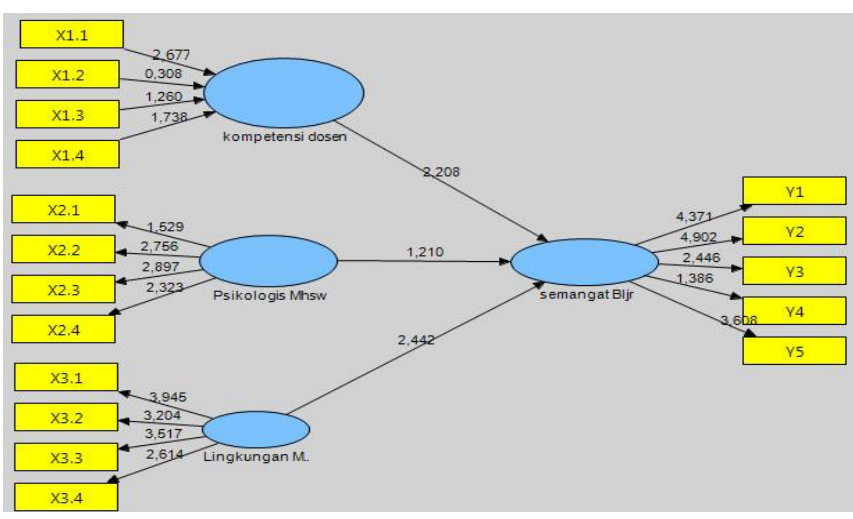

Figure 2 - First Phase/Stage PLS Loading Value 
Table 3 - Value of t Calculate of the First Stage

\begin{tabular}{clccc}
\hline Notation & \multicolumn{1}{c}{ Indicator } & Construct & Loading & tcalculate \\
\hline X1.2 & Personality competence (X1.2) & Lecturer competence & $-0,084$ & 0,308 \\
X1.3 & Social Competence (X1.3) & Lecturer competence & $-0,683$ & 1,260 \\
X1.4 & Professional competence (X1.4) & Lecturer competence & 0,688 & 1,738 \\
X2.1 & Intellectual (X2.1) & Student Psychology & 0,464 & 1,529 \\
Y.4 & Appreciation in learning & Learning Spirit & 0,320 & 1,386 \\
\hline
\end{tabular}

Table 4 - Lecturer Competence PLS Results

\begin{tabular}{llccc}
\hline Notation & \multicolumn{1}{c}{ Indicator } & Loading & tcalculate & Information \\
\hline X1.1 & Pedagogical Competence $(X 1.1)$ & 0,956 & 2,677 & significant \\
X1.2 & Personality competence $(X 1.2)$ & $-0,084$ & 0,308 & Not significant \\
X1.3 & Social Competence (X1.3) & $-0,683$ & 1,260 & Not significant \\
X1.4 & Professional competence (X1.4) & 0,688 & 1,738 & Not significant \\
\hline
\end{tabular}

Table 5 - Student Psychology PLS Results

\begin{tabular}{llccc}
\hline Notation & \multicolumn{1}{c}{ Indicator } & Loading & tcalculate & Information \\
\hline X2.1 & Intellectual (X2.1) & 0,464 & 1,529 & Not significant \\
X2.2 & Talent (X2.2) & 0,684 & 2,756 & significant \\
X2.3 & Motivation (X2.3) & 0,820 & 2,897 & significant \\
X2.4 & Maturity (X2.4) & 0,616 & 2,323 & significant \\
\hline
\end{tabular}

Table 6 - Learning Environment PLS Results

\begin{tabular}{|c|c|c|c|c|}
\hline Notation & Indicator & Loading & tcalculate & Information \\
\hline X3.1 & Teaching (X3.1) & 0,733 & 3,945 & significant \\
\hline X3.2 & Environmental Atmosphere (X3.2) & 0,605 & 3,204 & significant \\
\hline X3.3 & Social environment (X3.3) & 0,716 & 3,517 & significant \\
\hline X3.4 & Academic ability (X3.4) & 0,578 & 2,614 & significant \\
\hline
\end{tabular}

Table 7 - PLS Results of Learning Enthusiasm/Spirit

\begin{tabular}{llccc}
\hline Notation & \multicolumn{1}{c}{ Indicator } & Loading & tcalculate & Information \\
\hline Y.1 & Passion \& desire to succeed & 0,723 & 4,371 & significant \\
Y.2 & Encouragement and Need in Learning & 0,825 & 4,902 & significant \\
Y.3 & Hopes / Dreams for the Future & 0,490 & 2,446 & significant \\
Y.4 & Appreciation in learning & 0,320 & 1,386 & Not significant \\
Y.5 & Interesting activities in learning & 0,629 & 3,608 & significant \\
\hline
\end{tabular}

Based on the first stage analysis can be summarized indicators that exiled from the construct as follows:

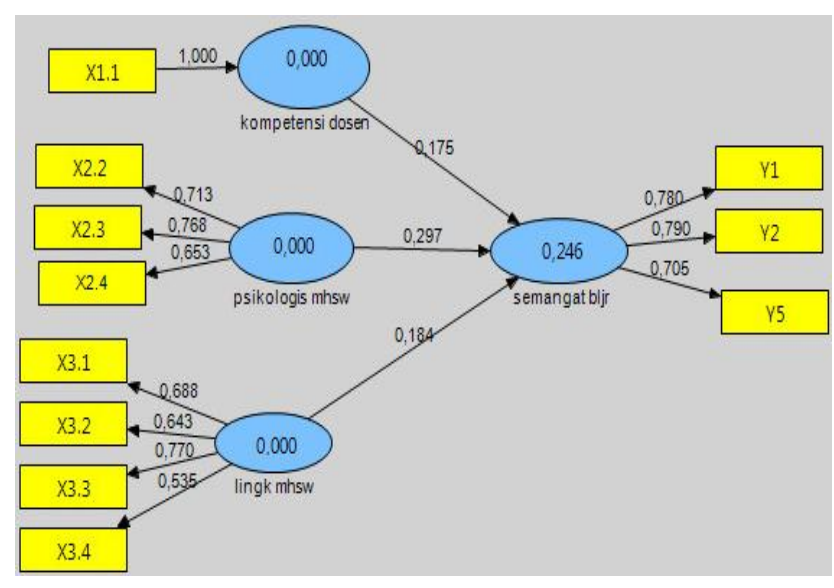

Figure 3 - Final Process PLS Analysis

Discriminant Validity used in the reflexive measurement model and calculated from the cross loading value on the manifest/indicator variable for each latent variable. If the 
correlation between latent variables with each indicator (manifest variable) the results are higher than the correlation with other latent variables, then the latent variable can be concluded predicting the indicator better than other latent variables.

Table 8 - Result of Loading and t Calculate of Final Process PLS

\begin{tabular}{|c|c|c|c|c|}
\hline Notation & Indicator & Construct & Loading & Tstat \\
\hline $\mathrm{X} 1.1$ & Pedagogic competence & Lecturer competence & 1,000 & 0,000 \\
\hline $\mathrm{X} 2.2$ & Talent & Student psychology & 0,713 & 4,736 \\
\hline$X 2.3$ & Motivation & Student psychology & 0,768 & 5,852 \\
\hline X2.4 & Maturity & Student psychology & 0,653 & 3,381 \\
\hline X3.1 & Teaching & Student environment & 0,688 & 6,342 \\
\hline X3.2 & environmental atmosphere & Student environment & 0,643 & 3,983 \\
\hline X3.3 & social environment & Student environment & 0,770 & 7,420 \\
\hline X3.4 & academic ability & Student environment & 0,535 & 3,010 \\
\hline Y1 & The existence of passion and desire to succeed & Learning spirit & 0,780 & 7,571 \\
\hline Y2 & The Existence of Encouragement and Need in Learning & Learning spirit & 0,790 & 10,456 \\
\hline Y3 & The Existence of Hopes / Dreams for the Future & Learning spirit & 0,705 & 6,942 \\
\hline
\end{tabular}

Table 9 - Discriminant Validity (Cross Loading Value)

\begin{tabular}{lcccr}
\hline & lecturer competence & Student environment & Student psychology & Learning spirit \\
\hline X1.1 & 1,000000 & 0,414168 & 0,246089 & 0,324291 \\
X2.2 & 0,191162 & 0,302104 & 0,713145 & 0,283997 \\
X2.3 & 0,217476 & 0,187962 & 0,767810 & 0,305466 \\
X2.4 & 0,113999 & 0,309630 & 0,652549 & 0,282541 \\
X3.1 & 0,324852 & 0,688215 & 0,266446 & 0,256012 \\
X3.2 & 0,351369 & 0,643143 & 0,196849 & 0,227046 \\
X3.3 & 0,189141 & 0,769786 & 0,337813 & 0,281130 \\
X3.4 & 0,255829 & 0,535185 & 0,159788 & 0,203813 \\
Y1 & 0,305548 & 0,228533 & 0,224896 & 0,779789 \\
Y2 & 0,263389 & 0,357898 & 0,378019 & 0,789989 \\
Y5 & 0,165248 & 0,221877 & 0,305156 & 0,704987 \\
\hline
\end{tabular}

Composite reliability shows the measure of internal consistency from the indicators of a construct that shows the degree in which the construct is formed.

Table 10 - Composite Reliability

\begin{tabular}{lcc}
\hline \multicolumn{1}{c}{ Construct } & Reliability & Information \\
\hline Lecturer competence & formative & \\
Student environment & 0,7567 & Reliable \\
Student Psychology & 0,7551 & Reliable \\
Learning spirit & 0,8028 & reliable \\
\hline
\end{tabular}

AVE values describe the magnitude of the variance or diversity of variable manifests that are owned by latent constructs. If the greater the variance or diversity of manifest variables that can be contained by latent constructs, then the representation of manifest variables to the latent constructs will also be even greater.

Table 11 - Average Variance Extracted (AVE)

\begin{tabular}{lcc}
\hline \multicolumn{1}{c}{ Construct } & Reliability & Information \\
\hline Lecturer competence & formative & \\
Student environment & 0,441566 & Quite good \\
Student Psychology & 0,507976 & good \\
Learning spirit & 0,576386 & good \\
\hline
\end{tabular}

Table 12 - Results of Hypothesis Test Using PLS

\begin{tabular}{clccc}
\hline Hip & Path & Coefficient & tcalculate & Information \\
\hline H1 & Lecturer competence $(\mathrm{X} 1) \rightarrow$ learning spirit $(\mathrm{Y})$ & 0,176 & 2,037 & significant \\
H2 & Student Psychology $(\mathrm{X} 2) \rightarrow$ learning spirit $(\mathrm{Y})$ & 0,297 & 2,268 & significant \\
H3 & Student environment $(\mathrm{X} 2) \rightarrow$ learning spirit $(\mathrm{Y})$ & 0,184 & 2,110 & significant \\
\hline
\end{tabular}


Based on the table above can explained that:

- Value of the path coefficient of lecturer competence $(\mathrm{X} 1) \rightarrow$ learning spirit $(\mathrm{Y})$ the magnitude is 0,176 with $t$ calculate 2,037. The value of $t$ calculate 2,037 $>1,96$ shows there is an influence of lecturer competence on learning spirit, the magnitude of influence is $17.6 \%$. The first hypothesis $(\mathrm{H} 1)$ which states that lecturer competence has a positive and significant effect on learning spirit of the student is accepted.

- Value of the path coefficient of student psychology (X2) $\rightarrow$ learning spirit (Y) amounted to 0,297 with $t$ calculate 2,268. The value of $t$ calculate 2,268 $>1,96$ shows there is an influence of student psychology on learning spirit, the magnitude of influence is $29,7 \%$. The second hypothesis (H2) which states that student psychology has a positive and significant effect on learning spirit of the student is accepted.

- Value of the path coefficient of student environment $(\mathrm{X} 3) \rightarrow$ learning spirit (Y) equal to 0,184 with $t$ calculate 2,110 . The value of $t$ calculate $2,110>1,96$ shows there is an influence of student environment on learning spirit, the magnitude of influence is $18,4 \%$. The third hypothesis (H3) which states that the student environment has a positive and significant effect on learning spirit of the student is accepted.

To answer the hypothesis simultaneously can be calculated by the F test as follows:

$$
\begin{gathered}
\mathrm{F}_{\text {calculate }}=\frac{R^{2}(n-k-1)}{k\left(1-R^{2}\right)}=5,981 \\
\mathrm{~F}_{\text {table }}=2,77
\end{gathered}
$$

Where: $R^{2}=R$ square; $n=$ number of respondents; $k=$ number of independent variables.

Because $F$ calculate $(5,981)>F$ table $(2,77)$, then it can be said there is simultaneously influence of lecturer competence, student psychology and the student environment on the learning spirit. So the fourth hypothesis $(\mathrm{H} 4)$ which states that there is simultaneously influence of the competence of lecturers, student psychology and student environment on the spirit of learning is accepted.

Based on the table above it is known that the greatest path coefficient on the influence of student psychology on learning enthusiasm/spirit. So the fifth hypothesis (H5) which states the competence of lecturers has a dominant value on learning spirit of the student is rejected.

To find out how much the independent variable of lecturer competence, student environment, student psychology explains the dependent variable of learning enthusiasm / spirit can be calculated with the formula of the goodness of fit index

$$
\mathrm{GoF}=\sqrt{\begin{array}{l}
\text { (communality lecturer competence } \mathrm{x} \text { Rsquare })+ \\
(\text { communality student environment } \mathrm{x} \text { Rsquare }) \\
\text { (communality student psychology } \mathrm{x} \text { Rsquare })
\end{array}}+=0,693
$$

These results indicate that the three independent variables mentioned above can explain the learning spirit amounted to $69,3 \%$.

\section{DISCUSSION OF RESULTS}

Influence of Lecturer Competence on Learning Spirit. Seeing the results of PLS analysis it is known that there is an influence of lecturer competence on learning enthusiasm/spirit. The results of the study support the results of previous studies by Elis Mediawati (2010), Hasan Basri, S.E., M.M. (2019) and Benget Simamora (2014).

In the results of the PLS analysis of the final process shows that pedagogical competence can significantly explain the construct of lecturer competence, while other competencies such as personality competencies, social competencies and professional competencies are not significant in forming lecturer competency constructs.

Competence is not merely technical, namely "the ability to manage the learners learning (PP RI No.19 of 2005). Based on the responses of respondent's shows that the 
response of students to pedagogical competence is very competent (mean 3,768 ). It can be said that the lecturer is able to provide an assessment of student learning outcomes according to student ability, lecturers are organized, orderly, and on time in conducting lectures and lecturers provide learning tools in the form of Learning Plans per Semester / Rencana Pembelajaran per Semester.

Regular, orderly, and timely lecturers in conducting lectures will increase the learning spirit of the student by trying to find knowledge from articles, the internet, textbooks, library books, and other sources in order to get maximum results.

Influence of Student Psychology on Learning Spirit. Seeing the results of PLS analysis it is known that there is an influence of student psychology on learning enthusiasm/spirit. The results of this study support the results of previous studies by Roy Setiawan (2010), Elis Mediawati (2010), Bipit Nindya Ningrum (2013).

The results of the PLS analysis in this study indicate that indicators of talent, motivation and maturity that form the psychological construct of students. Intellectual indicator is not significant. Talent indicators contribute $71,3 \%$, motivation indicators contribute $76,8 \%$, maturity indicators contribute $65,3 \%$ to the psychological construct of students.

The ability of students to have talent in economics increases the enthusiasm/spirit of students trying to seek knowledge from articles, the internet, textbooks, library books, and other sources so that they get maximum results. It is motivation that encourages students to carry out learning activities. Students' motivation to always think positively in solving problems encourages students to keep their enthusiasm/spirit for learning knowledge about science and life.

Students believe that the ability in economics will later help their careers in the future, this will affect students' enthusiasm/spirit for learning to increase their passion and desire to succeed by developing the material they have.

Influence of Student Learning Environment on the Spirit of Learning. Looking at the results of the PLS analysis it is known that there is an influence of the student's learning environment on learning enthusiasm/spirit. The results of this study prove the support for the results of previous studies by Roy Setiawan (2010), Hasan Basri (2019) and Bipit Nindya Ningrum (2013).

Based on the results of the PLS analysis shows that the teaching indicator contributes $68,8 \%$, the environmental atmosphere contributes $64,3 \%$, the social environment contributes $77,0 \%$ on the formation of the construct of the student learning environment. In this study, students stated that students always found books needed in the library, adequate lecture facilities and comfortable classrooms, adequate and clean bathroom facilities. An atmosphere like this can increase students' enthusiasm/spirit for learning to develop their material.

A good social environment will improve the atmosphere of learning to be conducive as well. As shown by the responses of students it is quite agreed that the social environment in Umaha can create free time filled with friends to discuss the material being taught.

\section{CONCLUSION} follows:

Seeing the results of the analysis and discussion of this study can be concluded as

- There is an influence of lecturer competence on student learning spirit equal to $17,6 \%$. Pedagogical Competency Indicators provide the largest contribution to the construct of lecturer competence;

- There is an influence of student psychology on student learning spirit equal to $29,7 \%$. Talent, motivation and maturity indicators contribute significantly to the formation of student psychology, but intellectual intelligence does not significantly shape students' psychology;

- There is an influence of student environment on student learning spirit amounted to $18,4 \%$. The indicators of teaching, the atmosphere of the environment, social 
environment and academic ability significantly shape the construct of the student's environment;

- Simultaneously there is the effect of lecturer competence, student psychology, and learning environment on learning enthusiasm/spirit;

- Among the lecturers' competence, student psychology, the learning environment that has a dominant value on student learning spirit is student psychology.

\section{SUGGESTIONS}

Personality competence, professional competence and social competence are not significant to the construct of lecturer competence. Maarif Hasyim Latif University should further enhance personal competence, professional competence and social competence. The enhancement of professional competence can be done by mastering the competencies to carry out the task and adhering to the learning assessment system can be oriented to results and processes. The enhancement of personality competence can be done by motivating yourself, acting with confidence and managing your own learning. Social competence can be improved by being able to build good and stable cooperation with other lecturers, education staff, students, and the community to support education.

Intellectual intelligence is not significant to the psychological construct of students. To improve the student psychology can be done by being able to think quickly in solving problems, be able to understand what is read, hear, and write and have a strong memory of what has happened.

Appreciation in learning is not significant to the construct of learning spirit. This can be done by giving praise on the exact time of task collection. Give added value to student attendance that is $100 \%$ attend in the taught subject. Give an appreciation when students can answer questions or provide solutions to problems raised by lecturers.

\section{REFERENCES}

1. Abdillah, W., Jogiyanto. (2014). Partial Least Square (PLS). Yogyakarta: Andi.

2. Agbo, S. A. (2002). Decentralization of First Nations education in Canada: Perspectives on ideals and realities of Indian control of Indian education. Interchange, 33(3), 281-302.

3. Banks, T., \& Dohy, J. (2019). Mitigating Barriers to Persistence: A Review of Efforts to Improve Retention and Graduation Rates for Students of Color in Higher Education. Higher Education Studies, 9(1), 118-131.

4. Benget, S. (2014). Pengaruh Disiplin and Kompetensi Dosen terhadap Prestasi Mahasiswa Program Studi Penerbitan. Jurnal Publipreneur. 2(4): 98-113.

5. Bipit N., N. (2013). Pengaruh Lingkungan Belajar and Motivasi Belajar terhadap Prestasi Belajar Mata Pelajaran Ekonomi Siswa Kelas XI Di Man Keboan Tahun Pelajaran 20122013. Hal 4-7. Pada Tanggal 13 Maret 2019.

6. Chaika, G. (2020). Psychological characteristics influencing personal autonomy as a factor of psychological well-being. Psychological journal, 6(1), 18-28.

7. Cleary, B. L., McBride, A. B., McClure, M. L., \& Reinhard, S. C. (2009). Expanding The Capacity Of Nursing Education: Until the pipeline for advanced education in nursing is flowing freely, the nation's nurse workforce will have difficulty achieving its potential. Health Affairs, 28(Suppl3), w634-w645.

8. Elis, M. (2010). Pengaruh Motivasi Belajar Mahasiswa and Kompetensi Dosen terhadap Prestasi Belajar. Jurnal Pendidikan Ekonomi Dinamika Pendidikan. 5(2): 134-146.

9. Fajariah, M., \& Suryo, D. (2020, February). Teacher's Education for Character Education. In 2nd International Conference on Social Science and Character Educations (ICoSSCE 2019) (pp. 311-320). Atlantis Press.

10. Hasan, B. (2019). Pengaruh Motivasi, Kompetensi Guru, and Lingkungan Belajar terhadap Prestasi Belajar Siswa Sekolah Menengah Kejuruan (SMK) An-Nur Bekasi. Hal 1-5. Pada tanggal 13 Maret 2019. 
11. Hota, P., \& Sarangi, P. (2019). Quality Revolution of Higher Education: A Study in India. Srusti Management Review, 12(1), 49-56.

12. Medina, M. A., Murtadha, K. H., \& Grim, J. (2020). Community Schools as a Vehicle for Social Justice and Equity. In Emerging Perspectives on Community Schools and the Engaged University (pp. 80-97). IGI Global.

13. Patel, G., \& Annapoorna, M. S. (2019). Public Education Expenditure and Its Impact on Human Resource Development in India: An Empirical Analysis. South Asian Journal of Human Resources Management, 6(1), 97-109.

14. Republik Indonesia. (2005). Peraturan Pemerintah No. 19 Tahun 2005 Tentang Standar Nasional Pendidikan. Lembaran Negara RI Tahun 2005 No. 41. Sekretariat Negara. Jakarta.

15. Roy, S., (2010). Analisis Pengaruh Faktor Kemampuan Dosen,Motivasi Belajar Ekstrinsik and Intrinsik Mahasiswa, serta Lingkungan Belajar terhadap Semangat Belajar Mahasiswa Di Departemen Matakuliah Umum Universitas Kristen Petra. Jurnal Mitra Ekonomi and Manajemen Bisnis. 1(2): 229-244.

16. Simonson, M., Zvacek, S. M., \& Smaldino, S. (2019). Teaching and Learning at a Distance: Foundations of Distance Education 7th Edition. IAP.

17. Sulisworo, D. (2016). The Contribution of the Education System Quality to Improve the Nation's Competitiveness of Indonesia. Journal of Education and Learning, 10(2), $127-$ 138.

18. Theron, L. C. (2004). The role of personal protective factors in anchoring psychological resilience in adolescents with learning difficulties. South African Journal of Education, 24(4), 317-321.

19. Thousand, J. S., Villa, R. A., \& Nevin, A. (2020). Salamanca Statement and Framework for Action on Special Needs Education, which supported the practice of inclusive education for students with disabilities, with the caution that while inclusive schools provide a favorable setting for achieving equal opportunity and full participation. Inclusive Schooling Practices Tip 45(3), 239-248. 